\title{
A Historical Analysis of Racism Within the US Presidency: Implications for African Americans and the Political Process
}

\author{
Dewey M. Clayton ${ }^{1}$ · Sharon E. Moore ${ }^{2}$ D . Sharon D. Jones-Eversley ${ }^{3}$
}

Accepted: 15 June 2021 / Published online: 2 July 2021

(c) The Author(s), under exclusive licence to Springer Science+Business Media, LLC, part of Springer Nature 2021

\begin{abstract}
This article examines the history of racism in the American presidency and the implications that it has had for Black residents of this country. The paper begins with a discussion of President Trump's racist rhetoric towards Blacks but notes that a history of racism is woven into the US presidency. We employ critical race theory as a theoretical framework to demonstrate why institutional racism has always been pervasive in the American presidency. Using a case study analysis, the authors conduct a comparative study of the history of racism of American presidents with the presidency of former president Donald J. Trump. The authors conclude that for most of the nation's history, racism and indifference to African Americans permeated the US presidency. It has only been since the advent of the second half of the twentieth century, for the most part, that there have been meaningful efforts by US presidents to address the concerns of African Americans.
\end{abstract}

Keywords US presidency · Racism - African Americans · Donald Trump - White supremacy

Dewey M. Clayton

dewey.clayton@louisville.edu

Sharon E. Moore

semoor02@exchange.louisville.edu

Sharon D. Jones-Eversley

SJoneseversley@towson.edu

$1 \quad 111$ Ford Hall, University of Louisville, Louisville, KY 40292, USA

2 Raymond A. Kent School of Social Work, 214 Oppenheimer Hall, University of Louisville, Louisville, KY 40292, USA

3 Family Studies \& Community Development, Towson University, 8000 York Road, Towson, MD 21252-0001, USA 


\section{Introduction}

Many in this country are relieved that Donald Trump is no longer President of the USA. As president, Donald Trump displayed a callous hostility towards Black people, in his rhetoric and his public policies. However, Trump's animosity towards African Americans is rooted in the vestiges of racial sentiment long held towards Blacks since the founding of this country. According to Ian Haney Lopez, a UCBerkeley scholar, “Trump's words can't be disconnected from this country's long history of racist stereotypes and discrimination" (Rascoe, 2018). Neither Trump's rhetoric nor negative sentiments towards racial minorities were new to the presidency. As president, Trump considered himself a nationalist, which many saw as a code word for being a white nationalist, meaning that the USA was founded on the premise of white supremacy and that Whites should do what they can to maintain that status quo.

Dr. Frances Cress-Wellsing cites Fuller's (1969) definition of white supremacy racism as a universally operating "system" of white supremacy rule and domination, in which most the world's white people participate (Cress-Wellsing, 1974, p. 32). After a careful examination of the socio-political and economic structures that have been developed by White people for the intention of claiming superiority and usurping dominance over Black people, she developed a seminal work, the "Theory of Color-Confrontation." Her theory states that "the white or color-deficient Europeans responded psychologically with a profound sense of numerical inadequacy and color inferiority upon their confrontations with the massive majority of the world's people all of whom possessed varying degrees of color producing capacity" (Cress-Wellsing, 1974, p. 34). Because of this insecurity, what ensued, on the part of Europeans, were sordid and sociopathic oppressive ways of interacting with those who were not White. Africans were enslaved and forcibly brought to America for the express intention of building and supporting the US economy. Since its inception, racism has been embedded in the American culture. Race is a distinct concept from racism but the two are related. A key element of racism is it is based on perceptions - both real and imagined differences among groups of people. Furthermore, those differences assign values that benefit one group at the expense of other groups (Bell, 2008). And power is distributed based on those real and perceived differences, creating structural inequity that benefits the perceived superior group and disadvantages the subordinate groups (Bobo, 2017). In this paper, the authors contend that racism is entrenched in all spheres of American society, is a historical aspect of the US presidency, and that it has been and is systematically manifested in various ways through executive policies and practices. Because of the outlandish, inordinate number of racist remarks that were directed at African Americans by former President Trump during his four years in office, one could easily believe that his contempt for Black people is not representative of past presidents. The authors will show that this is not the case by making comparisons between his racist acts and those of other presidents, beginning with George Washington.

An examination of the historical context will help readers understand the socio-political climate in which we presently live, in relation to past and present 
relationships between Whites and Blacks in the USA. We begin with a discussion of US scholars who examined the presidency through a racial lens. Next, we undertake a historical analysis of US presidents within this framework. Lastly, we hope that the implications discussed, relative to the lived experiences of African Americans, will help those in the human services and the political arena advocate for positive change in the life circumstances of Black people through the development of effective clinical practices and policy formation.

\section{Critical Race Theory}

According to Walton and Smith, "Race is the most important cleavage in American life, with enormous impact on the nation's society, culture, and politics" (Walton et al., 2021). Since Donald Trump first announced he was running for president of the USA in 2015, it was clear he would use racism as the centerpiece of his campaign to win the White House in 2016. In fact, while President Barack Obama was still in office, Trump began publicly questioning whether Obama was born in the USA and had a legitimate claim on being President of the USA because he was not a natural born citizen, which is required by Article II of the U.S. Constitution. This was essentially a modern version of an American precept that Black people are not worthy of being citizens of this country. Since being elected President in 2016, Donald Trump's racism has been on full display to this country and the world.

Trump, who ran for President as a Republican, a party that has long cultivated White voters, is one of all the American presidents, save one, to have benefitted from their "Whiteness." For this paper, the authors use critical race theory (CRT) to examine how racism is woven into the history of the US presidency. Critical race theory is an important framework for understanding racial and ethnic politics in America (Graham, 2007, p. 213).

CRT arose during the modern civil rights movement of the 1960s, and seeks to examine the relationship between race, racism, and power; it proposes that white supremacy and racial power are maintained over time (Crenshaw et al., 1995). CRT grew out of critical legal theory, but its ideas have had an influence on scholarly writings on race and ethnicity in other disciplines such as political science, education, ethnic studies, and feminist studies. "Law and politics are inextricably linked and CRT calls for a multidisciplinary approach to understanding the role of race in society" (Graham, 2007, p. 213). Derek Bell, one of the founders of CRT, advanced the interest convergence theory that racial progress in the area of civil rights is tied to white self-interest. In other words, civil rights progress for Blacks only occurs when the interests of Whites would be either advanced or not harmed (Bell, 2008).

Furthermore, CRT provides a historical context for analyzing modern forms of oppression. To that end, racial domination is structured in and through the social institutions that shape social relations. And the individuals who operate in the social institutions (education, health, legal systems, politics, economics, and criminal justice) follow the prevailing racial protocol (procedures, rules, etc.) of those institutions whose foundations are rooted in racism (Bonilla-Silva, 2014). So, the architects of the Constitution handled the question of slavery as an 
economic and political matter, not as a moral one (see below), though recognizing that slavery was incompatible with the ideals of "freedom and liberty" enunciated at the close of the eighteenth century (Bell, 2008, p. 37).

It is important to note that CRT seeks to examine the notions of equality and race through the lens of an oppressed people (Delgado \& Stefancic, 2001). CRT is instructive in explaining the white backlash to Barack Obama's presidency (2009-2016) and the rise of Donald Trump. After all, Obama and his family were the first Blacks to reside in the White House.

Whiteness appears to be at the core of Trump's power. He is the first president never to have previously held public office or served in the military before becoming President. Critical race theorist Cheryl Harris uses a theoretical approach to whiteness as property - the ultimate property that Whites alone can possess. She equates having white skin to being the owner of real property - it grants privileges to the owner that a renter (or a person of color) would not be granted (Harris, 1995).

Throughout history, presidents have issued executive orders, implemented public policies, and used the bully pulpit to make proclamations (and now tweets) that appeared race-neutral on their face. However, it becomes critical to recognize the systemic damage of many of these policies in areas such as criminal justice, civil rights, education, housing, the environment, and many others, though color-blind on their face, tend to disproportionately affect communities of color. Political scientist Barbara Luck Graham notes that

Critical race theory offers a harsh critique of traditional liberal principles while at the same time rejecting conservative visions of equality. Critical race theorists seek to uncover how appeals to color blindness, merit, neutrality and equality of opportunity actually hinder racial progress and contribute to the continual oppression of people of color (Graham, 2007, pp. 212-213).

Using critical race theory, we can understand the development of these policies through the prism of white supremacy and racial power. CRT helps us to understand how racism is woven into the history of the US presidency and has been sustained since the inception of this country.

\section{Historical Background}

Political Scientist Wilbur Rich argues the grand narrative of America is its unwavering commitment to freedom and equality (Rich, 2007, p. 232). However, to be faithful to these ideals, presidents must take on the issues of race forthrightly. Additionally, Rich asserts race relations still play only an "ancillary role in the discourse about the nature of the American presidency" (Rich, 2007, p. 232). As a result, he argues scholars treat civil rights as a footnote or simply do not discuss the issue at all-preferring to talk about foreign policy and defense of the nation from "real and imagined" enemies. History has taught us that presidents play a large role in reinforcing social boundaries. For example, Rich notes that some presidents "have reassured whites that racial boundaries will remain intact, while others have promised whites that they have little to fear from conceding privileges or that racial 
progress will not take place at their expense" (Rich, 2007, p. 233). Furthermore, Rich observes much of the scholarly discourse on the presidency addresses black civil rights grievances as an infringement on presidential time. Rich examines a variety of typologies on presidential leadership. He offers a typology of Presidents' racial acknowledgment gestures (RAGs) and situational improvement policies (SIPs) (Rich, 2007, p. 246). According to Rich, all Presidents, regardless of political ideology and party, have used RAGs. Rich defines RAGs as “... mainly symbolic, individual-specific, or event-specific, that do not result in any substantive change in the position of Blacks as a group" (p. 232). On the other hand, SIPs are "major policy shifts that result in substantial race hierarchical changes, and they apportion status, power, and resources to Blacks as a group" (Rich, 2007, p. 232). As an example, Rich says that President Theodore Roosevelt's 1901 dinner meeting with the Black educator Booker T. Washington at the White House, though considered an important breakthrough in racial etiquette, amounted to little more than a symbolic gesture or RAG in race relations. Rich argues the office of the presidency plays a critical role in the political progress of African Americans. Rich sees most US presidents as remaining neutral on racial conflicts or what President Richard Nixon's aide, Daniel Patrick Moynihan referred to as "benign neglect" (Rich, 2007, p. 233). As an example, Rich points to Franklin D. Roosevelt's refusal to support anti-lynching legislation. Furthermore, this gave solace to Whites committing those crimes. Lastly, Rich sees most presidents as having mixed records on civil rights for African Americans and only President Johnson's commitment to passing the Civil Rights Act of 1964 and the Voting Rights Act of 1965 as rising above a symbolic gesture and becoming situational improvement polices (p. 247).

In their seminal work, American Politics and the African American Quest for Universal Freedom, Walton et al. (2021), also acknowledge there are several typologies, and theories in the literature on presidential leadership (p. 274). They argue few studies have examined presidential accountability as it relates to race relations. They construct a typology of the racial attitudes and policy perspectives of American presidents from George Washington to Donald Trump. They divide the presidency into seven periods: Revolutionary (1789-1829), Antebellum (1830-1860), Reconstruction (1863-1877), Post-Reconstruction (1880-1930), Civil Rights (1930-1970), and Post-Civil-Rights (1970-forward). They identify each president along the following continuum: (1) White Supremacist, (2) Racist, (3) Racially Neutral, (4) Racially Ambivalent, and (5) Anti-racist (pp. 275-278). They base the attitudes and racial policies of the presidency on information obtained by various biographical sources including the entire University Press of Kansas American Presidency series and other works by presidential historians (p. 278). After examining all the presidents (save President Joe Biden) they conclude that most of them have not been very sympathetic to the plight of African Americans and their quest for universal freedom and that most were either hostile, neutral or ambivalent in their approach towards African American freedom. It is noteworthy that the authors classify all the antiracist presidents except for Abraham Lincoln, Ulysses S. Grant, and Benjamin Harrison, as having served in office since the middle of the twentieth century, primarily since the 1960s (p. 274). They conclude most American presidents have been unresponsive to Black Americans' quest for universal freedom. 
In his book, The Presidency and the Politics of Racial Inequality, political scientist Russell L. Riley argues that the presidency is a nation-maintaining institution on the issue of racial inequality. "One of the enduring roles each president is required to execute is that of nation-keeper, a protector of the political and social order and a preserver of domestic tranquility" (Riley, 1999, p. 10). So, Riley, in essence suggests that presidential behavior is intended to "... ward off or moderate significant social change as a threat to the perceived status of the polity's prevailing interest" ( $\mathrm{p}$. 10). Moreover, notes Riley, there is a duality to this role. Nation-keeping presidents may find, in some instances, that profound change is a prerequisite for preservation. According to Riley, "Most conventional portraits of the presidency... all but ignore that first dimension and tend to underscore the conditionality of the second" (p. 10).

In African Americans and the American Political System (Barker et al., 1999), Lucius Barker, Mack Jones, and Katharine Tate assert that "whether a president supports a range of issues important to African Americans will depend on the overall shape of American politics" (p. 307). Presidential views and attitudes on all political issues are largely based on the incumbent president's conception of the presidency. Because of this, some presidents may see their office as an instrument for change while others see their role much more narrowly. They contrast the view that many held of President Kennedy and President Johnson in the civil rights struggle to that of President Eisenhower, who for the most part, limited his role to the execution and implementation of the existing laws (p. 307). While acknowledging that the president has enormous influence in setting the nation's agenda, they posit that "... African Americans tend to focus on the person or the office in their quest for social justice. However, to be successful, Blacks need to get the president to support their causes" (p. 307). The common thread running through all of these studies is that they highlight the specific behavior of what motivates US Presidents and their executive politics and policy on race.

\section{A Case Study of US Presidential Racism}

The legal chattel system of enslavement and unpaid labor of Blacks is woven into the American history and US presidency (Perea, 2010; Van der Zee, 1985). The White House was built in 1792 by Black slaves (Holland, 2016; White House Historical Association, 2020), and Black indentured servants worked inside the White House (Associated Press, 2008). All 46 US presidents took an oath that they would, "preserve, protect, and defend the Constitution of the United States" (Article II, U.S. Constitution), but despite this constitutionally-binding oath, not all the US Presidents have acted justly on behalf of all US citizens. Racism, a racial superiority belief that White people and their needs take precedence over that of other racial and ethnic individuals and groups, has been and remains the infectious bigotry that polarizes the American presidency and its culture (Macedo et al., 1999; Pieterse \& Powell, 2016). When racism infiltrates the US presidency, its discriminatory White supremacy ideologies concurrently violate the President's constitutional oath and inhibits the President from executing his duties on behalf of all US citizens (Associated Press, 2019; Feagin, 2004). 
The USA is replete with examples of presidents who were racists before taking office and while in office. This, however, should come as no surprise given that this nation was founded on racism; the founding document of this country, the U.S. Constitution, gave its imprimatur to this by condoning the institution of slavery and would make the protection of property rights foremost. The architects of the Declaration of Independence and the U.S. Constitution (all White males) felt the Black African slaves brought to America in the early 1600s were an inferior race. Many of the founding fathers were heavily influenced by the Enlightenment Period in Europe in the eighteenth century. White supremacist' notions were pervasive in the writings of the major figures of the Enlightenment Period among such men as Montesquieu, Voltaire, Kant, and Locke. Jefferson, the architect of the Declaration of Independence, who embraced the political values of the Enlightenment Period, in referring to Blacks would write in his book, Notes on the State of Virginia (1785), "Comparing them by their faculties of memory, reason, and imagination, it appears to me, that in memory they are equal to Whites; in reason much inferior... and in imagination they are dull, tasteless anomalous" (Jefferson \& Magnis, 1999, p. 494).

Very few studies have addressed presidential accountability as it relates to race relations (Walton et al., 2021). However, of the 45 presidents this country has elected (Grover Cleveland was elected twice to nonconsecutive terms), few of them have been staunch advocates of the Black liberation struggle. From the country's first president, George Washington, whose term began in 1789, to Zachary Taylor, the 12th president, who served until 1850, many of our presidents owned slaves. Thus, they held political power at a time when most African Americans, slave or free, were denied the right to vote or to hold political office and were denied service in public accommodations and the ability to earn a decent wage (Contreras, 2019).

George Washington commanded the Continental Army during the American Revolutionary War and presided over the Constitutional Convention in 1787. Despite the moral imperatives of the new nation expressed in the Declaration of Independence and embodied in the Constitution and the Bill of Rights, the founding fathers approached slavery as an "economic and political, rather than a moral matter" (Bell, 2008). Furthermore, the Constitution, as a legal document, sanctioned slavery. As the principal founding father, Washington owned slaves on his Mount Vernon plantation in Virginia and when he became the first president and moved to Philadelphia, then the seat of the nation's capital, he took slaves with him. Upon his death in 1799, he had not freed any of his slaves, but he did stipulate in his will that his slaves be freed.

Thomas Jefferson, the nation's third president, felt that if slaves were ever freed, they should be deported based on his belief that Blacks and Whites could not live peacefully together. Jefferson, the main author of the Declaration of Independence, which espoused the principles "all men are created equal and born with unalienable rights," never meant for those lofty precepts to apply to African Americans. Ironically, Jefferson (though considering Blacks as inferior human beings) had a long-term sexual relationship with Sally Hemings, a slave with whom he fathered six children.

Andrew Jackson, the seventh US president and a slave owner from Tennessee, took office in 1829. Ironically, Jackson is known for the expansion of democracy 
and extending the right to vote to the common White male. However, not everyone was included in the new Jacksonian Democracy. Jackson was born into poverty and rose to wealth, largely because he personally embraced the institution of slavery. He owned slaves which he used to build his fortune. When he became president, he brought enslaved Americans to the White House to work for him. Walton, Smith, and Wallace sum up this period best when they state none of the early presidents favored universal freedom for Blacks. Additionally, none of the nine presidents during the antebellum era (1830-1860), took any action in response to African Americans' demands for freedom being made by the abolitionist movement (Walton et al., 2021).

\section{The Reconstruction Era}

During the Civil War (1861-1865), Republican President Abraham Lincoln issued the Emancipation Proclamation on January 1, 1863, holding that all persons held as slaves within the rebellious states are free. In 1865, Congress passed, and the states ratified the first of three Civil War Amendments. These amendments to the U.S. Constitution were an attempt by the US national government to bestow the full rights and privileges of citizenship on all Americans. In 1865, the 13th Amendment abolished slavery throughout the USA. In 1868, the 14th Amendment granted full citizenship rights to the formerly enslaved Americans and gave them "equal protection of the laws" of the USA, and in 1870, Congress passed the 15th Amendment granting all African American males the right to vote.

Democrat Andrew Johnson became the 17th president of the USA upon the assassination of President Abraham Lincoln in 1865. Many historians point to Johnson's racism as ending the Reconstruction Era. As president, he vetoed civil rights legislation and the Freedman's Bureau Act (an agency set up by Congress to provide practical aid to the four million newly freed African Americans in their transition from slavery to freedom) which Congress overrode (Priess, 2018). By far, more than any other president in the history of this nation, Johnson halted the progress of African Americans to claim their rightful social, political, and economic rights, which had a devastating effect on their march to equality for decades to come (Franklin \& Moss, 1988, pp. 205-207).

The Reconstruction Era did not end or begin at one particular time. Many scholars, however, effectively highlight the Hayes-Tilden Compromise of 1877 as the beginning of the death knell for Reconstruction. Republican Rutherford B. Hayes assumed the presidency after a controversial election against Samuel Tilden that was decided ultimately by a committee of 15 from the US Senate, the US House of Representatives, and the US Supreme Court. As a result, Hayes withdrew federal troops that were stationed in the South, and the South began to deny to Blacks the social and political rights they had only recently begun to enjoy. Historian John Hope Franklin writes that "not even the Supreme Court postponed the overthrow of Radical Reconstruction." In 1896, in the landmark U.S. Supreme Court case, Plessy v. Ferguson, the Supreme Court upheld the doctrine of "separate but equal" which legally created a racial caste system in America and effectively reduced Black Americans to second-class citizens 
in all areas of American life. Political scientist Russell Riley would note that presidents from the era of Rutherford B. Hayes (1877-1881) to Herbert Hoover (1929-1933), did very little to advance the cause of civil rights. He argues, to the contrary, “... these presidents used their offices to moderate or to stifle active movement toward racial equality" (Riley, 1999, p. 125).

Woodrow Wilson, the first Democratic candidate for president to receive significant Black support (Walton et al., 2021), was elected the 28th president of the USA in 1912. However, upon taking office, he immediately segregated the federal bureaucracy in Washington, D.C. by race. As president, he screened the racist film "The Birth of a Nation" at the White House as it premiered in 1915. The movie mythologized the Ku Klux Klan, a terrorist organization of poor, rural Whites, as heroes, and portrayed African Americans (Whites in blackface) as uncivilized, simple-minded, sexual predators of White women (Hoag, 2018). The movie had a lasting negative impact on African Americans and their roles in the movie industry.

Republican President Herbert Hoover became the $31^{\text {st }}$ president in 1928 at the beginning of the Great Depression and was a supporter of the "Lilly White Movement" which was an anti-African American movement within the Republican Party. According to scholar Daphney Daniel, Hoover did everything he could to drive Blacks out of the Republican Party. African Americans, most of whom still lived in the South as tenant farmers, were hit especially hard by the Great Depression in 1929, but Hoover ignored their pleas for assistance and the racial violence they increasingly were subjected to (Daniel, 2012, pp. 2-4). As a result, many Blacks living in the South continued to migrate to the North, looking for better economic opportunities and relief from the constant violence perpetrated against them by Southern whites.

Democrat Franklin D. Roosevelt (FDR) soundly defeated Herbert Hoover in the presidential election of 1932, but he won with only a handful of Black votes. Roosevelt's array of federal programs to put America back to work were collectively known as the "New Deal." The implementation of these programs caused a dramatic shift of power to the national government and offered renewed hope for African Americans. The creation of the numerous federal agencies held promise for many African American tenant farmers (mostly in the South) that their conditions would improve. However, many of the administrators of these federal relief programs denied federal assistance to African Americans (Daniel, p. 5).

Ironically, although in office for slightly more than 12 years, FDR was reluctant to advance civil rights for African Americans. Although many northern Whites did not share the racial attitudes of southern Whites, FDR accommodated the prevailing racism because he needed support from segregationist Southern Democrats (many of whom were committee chairs) in the US Congress to be able to pass his New Deal legislation (Katel, 2018, p. 263). FDR, at the urging of First Lady Eleanor Roosevelt, met with a group of African American leaders who wanted him to integrate the armed forces - FDR promised to do so but it was left to his vice president and successor, President Harry Truman, to integrate the armed services by executive order in 1948.

Truman took a strong position on civil rights and proposed a civil rights reform agenda to Congress, including outlawing the poll tax, anti-lynching legislation, and 
a ban on employment discrimination. He ordered an end to discrimination in federal employment and directed the Justice Department to file a brief in support of school desegregation cases pending before the US Supreme Court. Truman believed support for civil rights was a Cold War imperative -- as a leader of the "free world" the Soviet Union would criticize the US if we continued to maintain racism as a national policy (Walton et al., 2021, p. 281).

President Dwight D. Eisenhower, a Republican, assumed the presidency in 1953. During his two terms in office, he was cautious on the issue of civil rights. Eisenhower felt the federal government should let the individual states decide on that issue. However, where the federal authority did apply, such as in Washington DC, and on military bases, Eisenhower persisted on integration. In 1957, he would order federal troops to Little Rock, Arkansas, to keep the governor from denying nine Black students from integrating Central High School. Furthermore, Eisenhower signed the Civil Rights Act of 1957 into law - though mostly ineffective, it was the first civil rights legislation passed by Congress since 1865 (Sitkoff, 2008, pp. 29-31).

In 1960, John Kennedy, a Democrat, would run for president against Richard Nixon, a Republican, and win in a close election with $68 \%$ of the Black vote. There were high hopes in the Black community because of Kennedy's support among Black voters. As the 35th president of the USA, in 1963 he would give the first speech on race by an American president since Abraham Lincoln and call on Congress to pass a Civil Rights bill outlawing discrimination in all areas of public accommodation. Kennedy was assassinated in Dallas, Texas, in 1963, and Lyndon Johnson, his vice president, became the 36th president. Johnson pledged to see that Kennedy's Civil Rights bill became law. In 1964, Johnson ran for election and soundly defeated Republican Senator Barry Goldwater who voted against the Civil Rights Act of 1964 (Walton et al., 2021).

Johnson's support of Civil Rights legislation and white hostility to civil rights caused southern Democrats to begin abandoning the party which they felt no longer protected their interests. In a span of four years, Johnson would convince Congress to pass three landmark civil rights laws: the Civil Rights Act of 1964, the Voting Rights Act of 1965, and the Fair Housing Act of 1968 (Walton et al., 2021). President Johnson chose not to seek reelection in 1968. Republican Richard Nixon capitalized on this Southern discontent with the Democratic Party and ran on a "Southern Strategy." By using racial code words like "busing" and "law and order" to appeal to disaffected white voters in the South, Nixon won the presidency in 1968 by a landslide. Shortly after taking office, Nixon refused to meet with the newly formed Congressional Black Caucus in 1969 (Greenblatt \& Marshall, 2015, p. 86).

The Republicans would use race and "dog whistle" politics as the centerpiece of their election campaigns and go on to win all but one of the next six presidential elections. According to scholar Ian Haney-Lopez, dog whistle racism allows a level of plausible deniability, permitting the perpetrator to feign ignorance (Haney-Lopez, 2014). Republican Ronald Reagan was the most successful and effective white backlash politician in the post-Brown era. During his campaign for the presidency in 1980, Reagan used dog whistles to White voters with references to "welfare queens" and "strapping young bucks" to disparage African American women and men (Haney-Lopez, 2014). 
The civil rights era had ended, and Reagan appeared to exploit white resentment. As soon as Reagan took office in 1981, he tried to dismantle affirmative action programs by naming executive and judicial appointees with no appetite for civil rights enforcement (Rossinow, 2015). Reagan announced a War on Drugs in 1982 and his administration enthusiastically publicized "crack cocaine" in inner cities to help build support for the war (Alexander, 2010). This "War" had a devastating effect on Black and Brown communities throughout America.

Republican presidential candidate George H. W. Bush would put racial politics front and center when he ran for president in 1987-1988. His campaign produced a television advertisement that accused his Democratic opponent, Michael Dukakis, of being soft on crime and "coddling criminals." The ad stated that under a Massachusetts furlough program, a murderer sentenced to life in prison without parole raped a woman and assaulted her husband while being released on a weekend furlough (Katel, 2011, p. 96). The perpetrator, Willie Horton was Black, his victim White. Bush would go on to defeat Dukakis and become the nation's 41st president.

Bill Clinton, a Democrat, would challenge Bush's reelection bid for the presidency in 1992. In setting himself apart from his opponent, Clinton would go on the Arsenio Hall Show and play the saxophone in front of a live audience. A seminal moment during the campaign was when Clinton chastised Black rapper Sister Souljah for her violent rap lyrics. It was a way for Clinton to distance himself from African Americans and appeal to white moderates who considered him too sympathetic to Black interests (Bell, 2008). Once again, a white presidential candidate used dog whistles to appeal to White voters. After becoming the 42nd president by defeating George H. W. Bush in 1992, Clinton followed up on a campaign pledge to get tough on crime as president in 1994 by signing the largest anti-crime bill in history into law mandating life imprisonment without parole after three violent or drug trafficking convictions and $\$ 30$ billion for state and local prison grants and expansion of state and local police forces (Alexander, 2010).

Republican President George W. Bush (Bush II) took office in 2001, after defeating Democrat Al Gore. Bush did something no other president had ever done: he nominated African Americans to top-tier cabinet roles. He named Colin Powell as Secretary of State during his first term and subsequently selected Condoleezza Rice to the position during his second term as president. Furthermore, Bush II signed the Voting Rights Reauthorization Act into law, which renewed the Voting Rights Act for 26 years. However, Bush will long be remembered for Hurricane Katrina in 2005 where residents of New Orleans were hardest hit by flooding and homelessness and more than $40 \%$ of the dead were African American. His administration was widely criticized for its delayed response to the hurricane and the perceived lack of humanity to the plight of Blacks in despair (Greenblatt \& Marshall, 2015).

On November 4, 2008, Democrat Barack Obama was elected the 44th president of the US. He was the first African American to rise to the highest political office in this nation. President Obama built a coalition of Blacks, Latinos, young people, and White professionals. He would win reelection in 2012 but also sparked a backlash among Whites as the white portion of the presidential 
electorate continued to steadily decline from 87\% in 1992 down to 69\% in 2016. Scholar Ashley Jardina argues in her book White Identity Politics, the backlash from the election of the first African American president -- plus the demographic changes pointing to an America that was projected to be a non-white majority by the middle of the twenty-first century -- led to the rise of Donald Trump (Jardina, 2019).

\section{Trump's Appeal to Racism and White Supremacy}

When Republican Donald Trump announced his candidacy for president of the USA in 2015, his opening act was not a bold policy statement but a nativist appeal to racism, fear, and anti-immigration. After descending the escalator at Trump Tower in New York to officially "throw his hat into the ring," Trump unabashedly asserted "When Mexico sends its people, they're not sending their best... They're bringing drugs. They're bringing crime. They're rapists..." (Gamboa, 2015, p. 1). At first glance, it may appear odd that these remarks are the launch of a presidential campaign. But this would become the hallmark of Trump's campaign rhetoric. He would run a successful populist campaign for the presidency based on racial resentment and anti-immigrant sentiment (Hooghe \& Dassonneville, 2018). Racism undergirded Trump's campaign demagoguery from the beginning (Konrad, 2018).

When Trump began considering a bid for the presidency, he floated a birther conspiracy theory that President Obama was not born in the US and had no legitimate claim on being the president (Abramson, 2016). Candidate Trump and President Trump made a dog whistle call to a loose assemblage of white nationalists, white supremacists, neo-Nazis, white separatists, and paleo-conservatives, all under the banner of the alternative right or alt-right. From the moment Donald Trump first announced he was running for president of the USA in 2015, it was clear he would use racism as the centerpiece of his campaign to win the White House in 2016. After becoming the 45th US president, Donald Trump's racism was on full display to the country and the world. Trump began retweeting white nationalist and neo-Nazi messages such as fictitious crime statistics saying that a supermajority of 2015 murder victims were killed by Blacks (Clemmitt, 2018). Steve Bannon, co-founder of Breitbart News (a far-right online news outlet) said in 2016 that Breitbart News "is the platform for the alt-right" (Clemmitt, 2018, p. 4).

In Charlottesville, Virginia, in August 2017, a loose coalition of disgruntled proWhite, far-right reactionaries calling themselves the "alt-right" assembled to protest the planned removal of a statue of Confederate General Robert E. Lee, chanting slogans such as "White lives matter" "Jews will not replace us" and "blood and soil." Violence broke out the first night and the next day with a smaller group of anti-protesters where one of the anti-alt-right protesters was killed. Shortly thereafter, President Trump held a press conference and was asked about his response to the violent protests in Charlottesville. He replied by saying "you also had people that were very fine people, on both sides" (Holan, 2019). Trump not only helped raise the public profile of these various alt-right groups, but one of his senior policy advisers, Stephen Miller, gave the group a voice in government policymaking (Clemmitt, 2018). 


\section{Make America Great Again (MAGA)}

The demographics in the country are changing and political analysts, politicians, journalists, and voters are taking note. The increased fear of an overall loss of Whites in the country on top of non-White immigration to America, made conditions ripe for Donald Trump to run for president. Trump was able to appeal to conservative voters across America who feared loss of White racial and cultural dominance, but his appeal extended to white supremacist groups as well (Tavernise, 2018). Trump's call to "Make America Great Again" along with his fascist-tinged slogan "America First" were "dog whistles" to many conservative Whites in America who saw the left aligned with minorities (African Americans and Hispanics) who are driven by anti-White hatred and deeply troubled that the nation is becoming multiethnic. They feel Whites have lost their position of power and privilege and want to take it back (Clemmitt, 2018).

Trump's use of explicitly and implicitly racist appeals enabled him to gain the support of these white supremacist groups (Hartzell, 2018). Since Donald Trump became president, the country has seen the resurgence of fascism but in new forms (Giroux, 2017). This is evidenced quite visibly by his racial hatred. As president, President Trump had a Twitter following of 55 million people. That allowed him a massive bully pulpit to spew hatred, xenophobia, racism, and misogyny to target anyone that he perceived to be a threat.

While in office, Trump attacked four African American freshmen women of Congress (Reps. Alexandria Ocasio-Cortez of New York, Ilhan Omar of Minnesota, Rashida Tlaib of Michigan, and Ayanna Pressley of Massachusetts) known as "the Squad" and told them on Twitter they needed to "go back and help fix the totally broken and crime infested places from which they came." Ironically, all four are American citizens - three of the four were born in the USA and a fourth, Ilhan Omar, came as a refugee over 20 years ago. His words drew widespread condemnation and presidential historian Jon Meacham labeled Trump as the most racist president in American history alongside Andrew Johnson in the slavery era (Croucher, 2019). Trump's demagogic campaign rhetoric of building a wall to keep out Mexican immigrants and others coming to America from the southern border was followed up with an immigration policy that separated families coming to America seeking political asylum.

\section{Racism and Indifference}

What we found in our historical analysis of US presidents (see above) was a history of racism and indifference to African Americans throughout much of this nation's 236-year history. It was not until the second half of the twentieth century with the advent of the modern presidency that there were meaningful efforts on the part of some presidents to address the concerns of African Americans in this country with concrete policy solutions. Derek Bell, one of the founders of CRT, advanced the interest convergence theory that in America racial progress in the area of civil rights is tied to white self-interest. Black progress in the area of civil rights is contingent 
on the advancement of White interests (see above). As an example of this, President Abraham Lincoln, "the Great Emancipator" in a letter to newspaper editor Horace Greeley stated, "If I could save the Union without freeing any slave, I would do it; and if I could save it by freeing all the slaves, I would do it; and if I could save it by freeing some and leaving others alone, I would also do that..." (Bell, 2008). The Emancipation Proclamation was issued by Lincoln in 1863 primarily to win the war. Franklin Roosevelt, who had a tremendous opportunity to enact public policies favorable to Blacks in this country, failed to do so because of political reasons: he felt support for civil rights would jeopardize his coalition of voters which included a large bloc of southern white voters. However, Roosevelt's successor, Harry Truman was a staunch supporter of civil rights for African Americans. Furthermore, Truman saw the passage of civil rights legislation for Blacks as a cold war imperative. Many communist nations had reminded the USA of our treatment of African Americans whenever we attempted to extol the virtues of democracy around the world. Even during the civil rights era of the 1960s, only President Lyndon Johnson was courageous enough to support meaningful legislation to improve the lives of African Americans throughout the nation. For the most part, US presidents and their executive politics and policies to benefit African Americans have been ambivalent from the presidency of Franklin D. Roosevelt to the present, largely motivated by whether it would cost them the political support of white voters, and if they deemed it would, they would refrain from supporting or implementing those policies.

\section{Presidential Politics and Policies}

\section{Impact on Voting Rights}

Historically, Blacks have been denied the right to vote in this country. The 13th, 14th, and 15th Amendments to the U.S. Constitution (Civil War Amendments) were designed to bestow full citizenship rights on the newly free African Americans (see above). However, by 1870 , shortly after the passage of these amendments, the US Supreme Court began issuing a series of opinions that weakened federal protections by stating they did not apply to the actions of individuals (Kurlowski, 2019). As a result, southern states begin passing laws to disenfranchise Black voters. Some of the more notable of these laws included registration requirements, grandfather clauses, literacy tests, white primaries, racial gerrymandering, and poll taxes. Over time, all of these laws were declared unconstitutional by the US Supreme Court culminating in the passage of the Voting Rights Act (VRA) of 1965, which was designed to end the vote-denial and vote-dilution techniques that kept Blacks from voting. The VRA provided a vehicle for challenging current discriminatory laws, but also for preventing future discriminatory laws (Kurlowski, 2019). And the VRA had an immediate impact on Black voter registration in the South. The gap between Black and White registration rates declined substantially after passage of the VRA. For example, prior to the VRA becoming law in 1965, Black voter registration levels throughout the South were less than 50\% (Table 1). 
Table 1 Voter registration rates (1965 vs. 1988)

\begin{tabular}{|c|c|c|c|c|c|c|}
\hline & \multicolumn{3}{|c|}{ March 1965} & \multicolumn{3}{|c|}{ November 1988} \\
\hline & Black & White & Gap & Black & White & Gap \\
\hline Alabama & 19.3 & 69.2 & 49.9 & 68.4 & 75.0 & 6.6 \\
\hline Georgia & 27.4 & 62.6 & 35.2 & 56.8 & 63.9 & 7.1 \\
\hline Louisiana & 31.6 & 80.5 & 48.9 & 77.1 & 75.1 & -2.0 \\
\hline Mississippi & 6.7 & 69.9 & 63.2 & 74.2 & 80.5 & 6.3 \\
\hline North Carolina & 46.8 & 96.8 & 50.0 & 58.2 & 65.6 & 7.4 \\
\hline South Carolina & 37.3 & 75.7 & 38.4 & 56.7 & 61.8 & 5.1 \\
\hline Virginia & 38.3 & 61.1 & 22.8 & 63.8 & 68.5 & 4.7 \\
\hline
\end{tabular}

Source: adapted from Bernard Grofman, Lisa Handley and Richard G. Niemi, 1992. Minority Representation and the Quest for Voting Equality. New York: Cambridge University Press, at 23-24

However, by 1988, the voter registration gap between Whites and Blacks had closed substantially, so much that in some southern states, the percentage of Black and White registered voters was essentially equal.

\section{Impact on Voter Suppression}

In May 2017, shortly after taking office as President of the USA, Donald Trump established a Presidential Advisory Commission on Election Integrity. During his initial campaign for the presidency, Trump made repeated accusations of voter fraud. He won the Electoral College vote over Hillary Clinton 304 to 227 despite losing the popular vote by almost 3 million votes. Trump began tweeting in November 2017 he would have won the popular vote had it not been for the three to five million people who voted illegally. The purpose of the committee was to review voter fraud, improper registration, and voter suppression. On January 3, 2018, the Commission shut down after producing no real evidence that substantial voter fraud had occurred in the 2016 presidential election (Villeneuve, 2018). The commission was criticized by civil rights organizations, election law scholars, and many newspaper editorial boards as a pretext for its real goal of voter suppression (Tackett \& Wines, 2018). The commission had sought election information from the states on a substantial amount of information including social security numbers, political affiliations, and felony convictions. Vanita Gupta, president of the Leadership Conference on Civil and Human Rights, stated "The commission's entire purpose was to legitimize voter suppression" (Tackett \& Wines, 2018).

In 2006, the US Congress (with almost unanimous support from both the House and Senate), reauthorized Section 5 of the Voting Rights Act (VRA) and President George W. Bush signed the legislation into law. The VRA was originally passed by Congress and signed into law by President Lyndon B. Johnson in 1965 (see above). It affirmed the right to vote throughout the country and suspended literacy tests on a nationwide basis. It included special rules for states and localities ("covered jurisdictions," mainly in the South) with a history of racial discrimination, disallowing any election law changes in these places until they were approved by the 
US Department of Justice (DOJ). However, in Shelby County v. Holder (2013), the US Supreme Court struck down the formula for determining which states and localities were subject to these restrictions.

Since the Shelby decision, numerous states throughout the nation have implemented discriminatory voting practices (some under previously "covered" jurisdictions). These new practices include strict government-issued photo ID requirements, consolidation of polling places making it less convenient for minority voters, purging minority voters from voting lists under the pretext of voting list maintenance, the shortening or ending the days of early voting hours, and eliminating some same-day registration during the early voting period (Berman, 2015). Ironically, the essence of democracy - the right to vote - remains largely contested in this nation.

In the USA, millions of Americans have lost the right to vote due to felony criminal convictions. Felony disfranchisement laws around the country disproportionately affect African Americans and many of these laws are relics of the racist laws during slavery and Jim Crow in America. According to the Brennan Center (a non-partisan law and public policy institute), only three states have a state constitution that permanently disenfranchises citizens with past felony convictions but allow the governor to restore that right. Voting rights laws for convicted felons vary from state to state. If non-violent felons have paid their debt to society, they should have their full citizenship rights restored. Research shows that incarceration for African Americans has been used as a form of voter disfranchisement (Uggen et al., 2006).

\section{Conclusion}

In the USA, the presidency is the highest political office to which one can ascend. The American public expects that those in this position, especially during daunting times such as during the COVID-19 pandemic and racial unrest that is now occurring, will possess leadership qualities such as honesty, intelligence, character and integrity, vision for the country's future, and the ability to communicate with the public. The populace also wants a president who is compassionate towards the plight of all citizens and values the worth and dignity of all people, especially the disregarded and disenfranchised (Hasan, 2017; The Center for Creative Leadership, 2019). Systemic racism is pervasive throughout all of society and continues to rob many African Americans of the opportunity to live up to their fullest potential.

Former President Donald J. Trump began his campaign for the presidency, espousing a racist conspiracy theory that President Obama was not eligible to be president because he was born in Kenya. President Trump continued the tradition followed by most of the US presidents who preceded him with the implementation of policies and programs that continue to advantage Whites at the expense of Blacks and other minorities. The demographics in the country are changing, and the nation is becoming more racially and ethnically diverse. Blacks are no longer the largest minority group in the country at $12.9 \%$ of the population - Hispanics are the largest ethnic group at $16.7 \%$ of the population. Asians are the fastest growing minority group at $5.6 \%$ of the population. By the middle of the twenty-first century, demographers estimate this nation will be a majority minority country. Blacks will have the chance to 
substantially increase their political power by building coalitions with like-minded voters of all races and ethnicities so that the two major political parties can no longer ignore them. Furthermore, their political activism is reminiscent of the young Black protesters of the Civil Rights era. However, to exercise real political power these young activists will need to utilize their right to vote as well. A new coalition of Americans that are multiracial and multiethnic, and multigenerational chanting Black Lives Matter has seized the moment by taking to the streets with a new message of justice and equality and a renewed sense of hope for us all.

\section{References}

Abramson, A. (2016). How Donald Trump perpetuated the 'birther' movement for years. Abcnews.com. Retrieved from https://abcnews.go.com/Politics/donald-trump-perpetuated-birther-movement-years/ story? $\mathrm{id}=42138176$

Alexander, M. (2010). The New Jim Crow: Mass incarceration in the age of colorblindness. The New Press. Associated Press. (2008). Blacks in the White House: Slavery and servants. NBC News. Retrieved from http://www.nbcnews.com/id/28109794/ns/politics-white_house/t/blacks-white-house-slavery-service/\#. XhPBcFVKiM8

Associated Press. (2019). A history of racism is woven into the US presidency. US News \& World Reports. Retrieved from https://www.usnews.com/news/politics/articles/2019-07-30/presidentshave-made-racist-gestures-throughout-us-history

Barker, L., Jones, M., \& Tate, K. (1999). African Americans and the American Political System (8th ed.). Prentice-Hall Inc.

Bell, D. A. (2008). Race, racism, and American law (6th ed.). Aspen Publishers.

Berman, A. (2015). Give us the ballot: The modern struggle for voting rights in America. Farrar, Straus and Giroux.

Bobo, L. D. (2017). Racism in Trump's America: Reflections on culture, sociology, and the 2016 US presidential election. The British Journal of Sociology, 68, S85-S104.

Bonilla-Silva, E. (2014). Racism without racists: Color-blind racism and the persistence of racial inequality in America.

Daniel, D. (2012). How Blacks became blue: The 1936 African American voting shift from the party of Lincoln to the New Deal Coalition. Salve Regina University.

Clemmitt, M. (2018). 'Alt-right' movement. In Issues in race and ethnicity, Congressional Quarterly Researcher (8th ed., pp. 1-25). Washington, DC: CQ Press.

Contreras, R. (2019). A history of racism is woven into the US presidency. AP News. Retrieved from https://apnews.com/b0fe304f1 fad44e19e5ff4490ad1110c

Crenshaw, K., Gotanda, N., Peller, G., \& Thomas, K. (Eds.). (1995). Critical race theory: The key writings that formed the movement. New Press.

Cress-Welsing, F. (1974). The Cress theory of color-confrontation. The Black Scholar, 5(8), 32-40. https://doi.org/10.1080/00064246.1974.11431416

Croucher, S. (2019). Trump is most racist President since Andrew Johnson, says historian. Newsweek. Retrieved from https://www.newsweek.com/trump-racist-president-andrew-johnson-historian-tweet-1449449

Delgado, R., \& Stefancic, J. (2001). Critical race theory: An introduction. New York University.

Feagin, J. R. (2004). Toward an integrated theory of systematic racism. In M. Krysan \& A. E. Lewis (Eds.), The changing terrain of race and ethnicity (pp. 203-223). Russell Sage Foundation.

Franklin, J., \& Moss, A. (1988). From slavery to freedom (6th ed.). McGraw-Hill.

Fuller, N. (1969). Textbook for victims of White supremacy, Copyrighted. Library of Congress.

Gamboa, S. (2015). Donald Trump announces presidential bid by trashing Mexico, Mexicans. Retrieved from https://www.nbcnews.com/news/latino/donald-trump-announces-presidential-bid-trashing-mexicomexicans-n376521

Giroux, H. A. (2017). White nationalism, armed culture and state violence in the age of Donald Trump. Philosophy \& Social Criticism, 43(9), 887-910. 
Graham, B. (2007). Toward a critical race theory of political science. In W. Rich (Ed.), African American perspectives on political science (pp. 212-231). Temple University Press.

Greenblatt, A., \& Marshall, P. (2015). Changing U.S. electorate. In Issues in race and ethnicity, Congressional Quarterly Researcher (7th ed., pp. 73-102). Washington, D.C.: CQ Press.

Haney-Lopez, I. (2014). The racism at the heart of the Reagan presidency. Salon.com. Retrieved from https://www.salon.com/2014/01/11/the_racism_at_the_heart_of_the_reagan_presidency/

Harris, C. (1995). Whiteness as property. In K. Crenshaw, N. Gotanda, G. Peller, \& K. Thomas (Eds.), Critical race theory: The key writings that formed the movement. New York, NY: New Press.

Hartzell, S. L. (2018). Alt-White: Conceptualizing the "Alt-Right" as a rhetorical bridge between White nationalism and mainstream public discourse. Journal of Contemporary Rhetoric, 8(1/2), 6-25.

Hasan, S. (2017). Top 10 leadership qualities that make good leaders. TaskQue. Retrieved from https:// blog.taskque.com/characteristics-good-leaders/

Hoag, C. (2018). Diversity in Hollywood. In Issues in race and ethnicity, Congressional Quarterly Researcher (8th ed., pp. 53-77). Washington, DC: CQ Press.

Holan, A. D. (2019). In context: Donald Trump's 'very fine people on both sides' remarks. Politifact. Retrieved from https://www.politifact.com/article/2019/apr/26/context-trumps-very-fine-peopleboth-sides-remarks/

Holland, J. J. (2016). The invisibles: The untold story of African American slaves in the White House. Rowman \& Littlefield.

Hooghe, M., \& Dassonneville, R. (2018). Explaining the Trump vote: The effect of racist resentment and anti-immigrant sentiments. PS: Political Science \& Politics, 51(3), 528-534.

Jardina, A. (2019). White identity politics. Cambridge University Press.

Jefferson, T., \& Magnis, N. E. (1999). Thomas Jefferson and slavery: An analysis of his racist thinking as revealed by his writings and political behavior. Journal of Black Studies, 29(4), 491-509.

Katel, P. (2011). Race and politics. In Issues in race and ethnicity, Congressional Quarterly Researcher (5th ed., pp. 81-105). Washington, DC. CQ Press.

Katel, P. (2018). Racial conflict. In Issues in race and ethnicity, Congressional Quarterly Researcher (8th ed., pp. 255-280). Washington, DC. CQ Press.

Konrad, A. M. (2018). Denial of racism and the Trump presidency. Equality, Diversity and Inclusion: An International Journal, 37(1), 14-30.

Kurlowski, D. (2019). Rules matter: Election law revealed. West Academic Publishing.

Macedo, D. P., Bartolomé, L. I., \& Macedo, D. (1999). Dancing with bigotry: Beyond the politics of tolerance. St. Martin's Press.

Perea, J. F. (2010). Destined for servitude. University of San Francisco Law Review, 44(2), 245-252.

Pieterse, A., \& Powell, S. (2016). A theoretical overview of the impact of racism on people of color. In The cost of racism for people of color: Contextualizing experiences of discrimination (pp. 11-30). American Psychological Association. https://doi.org/10.1037/14852-002

Plessy v. Ferguson, 163 US 537 (1896).

Priess, D. (2018). How a difficult, racist, stubborn president was removed from power-If not from office. Politico. Retrieved from https://www.politico.com/magazine/story/2018/11/13/andrew-johnson-underminedcongress-cabinet-david-priess-book-222413

Rascoe, A. (2018). How President Trump interacts with the Black community. NPR. Retrieved from https:// www.npr.org/2018/09/06/645337114/how-president-trump-interacts-with-the-Black-community

Rich, W. (2007). Toward a critical race theory of political science. In W. Rich (Ed.), African American perspectives on political science (pp. 232-250). Temple University Press.

Riley, R. (1999). The presidency and the politics of racial inequality. Columbia University Press.

Rossinow, D. (2015). It's time we face the fact that Ronald Reagan was hostile to civil rights. History News Network. Retrieved from https://historynewsnetwork.org/article/158887

Shelby County v. Holder, 570 US 529 (2013).

Sitkoff, H. (2008). The struggle for Black equality. New York, NY: Farrar, Straus and Giroux.

Tackett, M., \& Wines, M. (2018). Trump disbands commission on voter fraud. The New York Times. Retrieved from https:/www.nytimes.com/2018/01/03/us/politics/trump-voter-fraud-commission.html

Tavernise, S. (2018). Why the announcement of a looming white minority makes demographers nervous. The New York Times. Retrieved from https://www.nytimes.com/2018/11/22/us/whiteamericans-minority-population.html

The Center for Creative Leadership. (2019). What are the characteristics of a good leader? Retrieved from https://www.ccl.org/blog/characteristics-good-leader/ 
Uggen, C., Manza, J., \& Thompson, M. (2006). Citizenship, democracy, and the civic reintegration of criminal offenders. The Annals of the American Academy of Political and Social Science, 605(1), $281-310$

Van der Zee, J. (1985). Bound over: Indentured servitude and American conscience. Simon \& Schuster.

Villeneuve, M. (2018). Report: Trump commission did not find widespread voter fraud. Associated Press. Retrieved from https://www.apnews.com/f5f6a73b2af546ee97816bb35e82c18d

Walton, H., Smith, R. C., \& Wallace, S. L. (2021). American politics and the African American quest for universal freedom (9th ed.). Routledge.

White House Historical Association. (2020). Slavery and the White House fact sheet. Retrieved from https://www.whitehousehistory.org/press-room/press-fact-sheets/slavery-and-the-white-house

Publisher's Note Springer Nature remains neutral with regard to jurisdictional claims in published maps and institutional affiliations. 